\title{
Onomastics and the Book of Good Love*
}

\author{
DOUGLAS P. HINKLE
}

T

HERE ARE THOSE WHo, with some considerable justification, have tended to regard the Book of Good Love, or Libro de buen amor, as a brilliant flash on the horizon of a Spanish Renaissance that never quite came off - at least not in the French or Italian manner. Certainly this work is one of the most amazing to come out of the European Middle Ages: amazing and puzzling, as was its author, the delightfully irreverent Archpriest of Hita. ${ }^{1}$ Throughout its 1728 stanzas, which fill two volumes in the Clásicos castellanos edition, ${ }^{2}$ there is a rollicking good humor and a lively interest in every facet of human knowledge of the day. All of Medieval society is represented: saints and sinners, nobles and clergy, shepherds and shepherdesses, millers, bawds, procuresses, nuns, and even animals talking, fighting, singing, praying or making love, as the case may be. Allegorical figures such as Lady Lent and Sir Carnival do battle in the lists of medieval theology. ${ }^{3}$ An archpriest sings the praises of the Blessed Virgin and mourns the death of his favorite procuress, almost in the same breath. Allusions to pagan mythology and to classical literature follow one upon the other, and ribald stories are backed up against sensitive religious poems that border on outright

* Read at the Annual Meeting of the ANS in Chicago, Dec. 30, 1965.

1 Juan Ruiz, of whom very little is known aside from the place of his birth or residence (Alcalá de Henares) and the approximate dates of the composition of his Libro. His imprisonment by order of don Gil is hypothetical. Cf. L. G. Moffatt, "The Imprisonment of the Archpriest," Hispania, Nov., 1950.

2 Arcipreste de Hita, Libro de buen amor, Edición y notas de Julio Cejador y Frauca, Espasa-Calpe, Madrid, 1951. The figure 1728 includes two cantares de ciegos at the end. This edition is based on Manuscript $G$ (Gayoso), which is the oldest extant (1389). The other two ms. are T (Toledo) and S (Salamanca). Ms. G is the property of the Academia Española.

3 The theme of Sir Carnival and Lady Lent was also a favorite in the plastic arts. A famous example is the painting by Pieter Breughel in the Kunsthistorisches Museum, Vienna. An early Flemish oil on the same theme is in the Boston Museum of Fine Arts. 
mysticism. Here is laughter, prayer, the grotesque, the absurd, the ludicrous, the beautiful, the moral and the immoral, blended together in one harmonious explosion of human energy that can fairly be termed a true forerunner of a great Renaissance.

Nowhere in this work is the zest for living, the joie de vivre, more apparent than in the Archpriest's use of names. If one accepts the premise that Juan Ruiz, the witty and frequently impious Arcipreste de Hita, was truly a child of his own times and that those times happened to coincide with the beginning of the Renaissance in Italy and elsewhere, then the proliferation of proper names in his work becomes less astounding if no less entertaining - and instructive.

There are more than 230 names in this manuscript. They are classified here into the following categories: religious or biblical names; place names; personal names; allegorical or coined names; and "other." Obviously this classification is by no means perfect, and frequently not even satisfactory. Often a name belongs as well in one category as another. For example, Galilea is both a place name and a Biblical name; and Ostiense occurs both as a patronym and as a toponym. Furthermore, the process of sub-classification involves the danger of infinity, which reaches the point of the absurd when a separate classification is established for every name - a not impossible circumstance in a work of the scope of the Libro de buen amor. Consequently sub-classification is held to the minimum consonant with a reasonable appreciation of Juan Ruiz' astounding erudition and universal interests.

\section{RELIGIOUS OR BIBLICAL NAMES}

It should be no cause for surprise that more than 35 per cent of all the names in the Libro de buen amor are religious in one way or another. The author was a clergyman in medieval Spain - that is to say, in a society that was totally immersed in religion in all aspects of daily life. What is indeed astounding is the extent of the Archpriest's mastery of his discipline. Here are the major figures of the Old Testament: Adam and Eve, ${ }^{4}$ Cain and Abel, Samson and Delilah, Abraham and Isaac. Uriah the Hittite and his somewhat in-

4 Biblical names and non-Spanish place names are anglicized throughout. For the Old Spanish equivalents as they occur in the Libro, an appendix is provided. 
constant wife Bathsheba appear together with David, a figure who inspired, one suspects, no little admiration on the part of the Archpriest, as much for his exploits in the boudoir as on the field of battle. Here also are Esther and Immanuel and Ezekiah and Job and Joab; Jacob, Jeremiah and Jonah; Solomon and Isaiah and Saul and Seth; Dan, son of Jacob; Lot; Ahasuerus, King of Persia who became the husband of Esther; and Japhet, son of Noah. The "bad guys" are present, too: Pharoah, Nebuchadrezzar and Satan, also referred to as Lucifer. The Angel Gabriel is mentioned three times, Moses twice, and God many times including once in the profane expression pardios, "by God."

New Testament names in the Libro run the course of Christ's Life. At the beginning are the three wise men, Balthasar, Gaspar and Melchior; and thirty-three years later, Pilate. Mary is represented five times as herself, once as a place name (Santa María del Vado) and twice in the expression Ave María. One finds the eternal Magdalene, and Judas, and Martha and Lazarus, sister and brother of Mary.

Jesus is mentioned numerous times, both by name and by the title Messiah.

A succession of saints parades across the pages: Augustine, whose Confessions included much raw material apparently admired by the Archpriest; St. Anthony, as protector of animals; St. John the Baptist, referred to only as Bautista; St. Paul; St. Gregory, probably the Great, because Gregory VII, though Pope in the eleventh Century, was not canonized until the seventeenth; Lazarus, patron saint of lepers; St. Mark; Santa Marina; St. Emeterius; St. Michael; St. Peter; St. Julian (Santillán), bishop of Cuenca, dear to the Archpriest for his reputation as an almsgiver; and St. Susanna. Also among ecclesiastical personnel is Innocent IV, who was not canonized and appears unlikely to be.

There is frequent reference to various religious orders: the order of St. Benedict, whose ancient and honorable beverage would surely not be spurned by the author of the Libro; the Order of Cluny; the Order of the Brothers of St. Eulalia; the Order of Hospitalers, the Cistercians and the Carmelites.

There are references to Christian works (Apocalypse, the Manual or confessor's handbook, and the Book of Wisdom); to Christian concepts identified by proper names (Purgatory, Lent, the Rosary, 
Christianity, the Gentiles, Immanuel, the Clementines, and Quasimodo or Whitsunday); and to non-Christian concepts (Allah, the Torah).

And finally one finds the Biblical place names: Babylonia, Bethlehem, Egypt, Galilee, Jerusalem, Judea, Nazareth and Israel.

\section{PLACE NAMES, NON-BIBLICAL}

As for non-Biblical place names in the Libro, it is convenient to divide them into Spanish and non-Spanish. Either category would provide material for years of research, for the Archpriest, like Rabelais, turned his Libro into something of a compendium of medieval knowledge. He mentions Alexandria, Bayonne, and Bologna; Bordones (Verdones) in Gascony; Brittany, the setting of one of his most famous ribald stories; Bugia (mod. Bougie) in Algeria between Tunis and Algiers; Flanders; Greece; Malines, a city in Belgium famous for its lace; Montpellier; Rome; the Tiber River; and Troy, whose most noted redhead was not likely to escape his notice.

But it is in Spanish place names that the Archpriest reaches the apogee of his enthusiasm. Here are names which came from the Romans, from the Arabs, from the Basques, from the Carthaginians and Phoenicians, and from the indigenous peoples themselves. Among the Arabic names one finds Alcalá, "the castle"; Alcántara, "the bridge"; Alcudia, "the rock, hill";" Algueva, "the cave"; $;$ Alberche, a tributary of the Tagus, and named after the perch; ${ }^{9}$ Andalucía <Al-Andalus, name given by the Moors to all Spain; and named in turn for the Vandals who had swarmed from the Pyrenees to North Africa. ${ }^{10}$

Among the Arab names are Caçres, "castle";11 Calata(y)ud, "castle of Ayub";12 and Calatrava < cala, "castle," + turab,

5 H. B. Richardson, An Etymological Vocabulary to the Libro de buen amor of the Arcipresta de Hita, New Haven, Yale University Press, 1930, p. 11.

6 Ibid. 7 Ibid.

8 Probably L. covam, 'cave,' in contamination with Ar. al-gobba. Cf. Enciclopedia universal ilustrada, Espasa-Calpe, Madrid, 1925. IV, 260.

9 Dozy \& Engelmann, Glossaire des mots espagnols et portuguais dérivées de l'arabe, Leyde, E. J. Brill, 1869, p. 71.

10 Richardson, Vocabulary, p. 18.

11 R. Menéndez Pidal, Orígenes del español, tercera edición, Espasa-Calpe, Madrid, 1950, p. 195. 12 Richardson, Vocabulary, p. 45. 
"earthwork." 13 One also finds Guadalajara and Guadalquivir, both compounds of Arabic wadi, "river" or "river bed." The former is thought to mean "river of the hegira," 14 though some have suggested "riverbed of stones." The latter, Guadalquivir, is generally agreed to be wadi-al-kibir, "the great river." 15

Among the names of Roman origin are Barcelona, Vera, ${ }^{16}$ Bermeo, ${ }^{17}$ Buenaval and Burgos. ${ }^{18}$ The name Buenaval interests the philologist because of the inversion of the two elements, buena and val. Normally in Spanish place names the generic element, in this case val, is proclitic upon the adjective, as in the usual form Valbuena. Also, L. vallem becomes val- only in proclisis. Thus it is clear that the generic element must originally have been in the proclitic position and transposed later. Proof positive is the retention of the diphthong /-ue-/ despite the fact that tonic stress no longer falls on that syllable, but shifts to -val in the form buenaval. This is an anomaly in Spanish place names.

Among the Latin place names whose roots are easily recognizable and whose meanings are clear are Castro; Castilla; Ferreros; Fita; Granada; Malangosto; Monferrado or Monserrado; Oropesa; Plasencia; Rio Frío; Sant Ander; Santiago; Sierra Nevada; Sotos Alvos; Tablada; Toro, Vado; Valdemorillo; Valencia; and Visagra, or via sacra.

Among those whose meanings are not immediately clear, but whose Latin etymologies are generally agreed upon by standard commentators are: Duero $<$ durium ; $;^{19}$ Fazalvaro $<$ faz + Alvaro, proper name; Medellyn, from the name of a Roman family, Metellus ; ${ }^{20}$ Laredo, possibly < lar, a god of the hearth, + L. -atium but more likely through redivision of $l a+$ ara + atium; Mongibel, from

${ }^{13}$ R. S. Charnock, Local Etymology: A Derivative Dictionary of Geographic Names, London, Houlston \& Wright, 1859, p. 55.

14 Richardson, Vocabulary, p. 73.

15 Ibid.

16 Enciclopedia universal ilustrada, VII.

17 Probably from bermejo, "red."

18 A nominative singular, common in O. Sp. place names. From burgus. W. MeyerLübke, Romanisches Etymologisches Wörterbuch, Carl Winters Universitätsbuchhandlung, Heidelberg, 1935. p. 129.

19 Enciclopedia universal ilustrada, XVII, 1038.

20 R. Menéndez Pidal, Manual de grámatica histórica española, quinta edición, Madrid, Victoriano Suárez, 1925. pp. 13-14. 
Latin montem + Arabic gebel, "mount mountain," 21 Ordiales, apparently < hort-, "garden," + toponymical suffix -ial(es);22 Troxillo $<$ turris iulia $;^{23}$ Valsavin $<v a l+$ sapinem $^{24}$ and Vyllenchón $<$ villa + ancha + -onem. ${ }^{25}$

Others, on which there is still some uncertainty, are Loçoya, Larcos, Moya and Requena. Soria, Sevilla, Segovia and Talavera are standard riddles for which numerous and often contradictory etymologies have been proposed.

There is Toledo, whose supposed Latin etymology, toletum, is meaningless. It appears to be a retroactive latinization. The inescapable fact is, the only meaning given for toletum in any Latin dictionary is "a place name in Spain." Obviously a name exists because of its meaning; and Latin toletum appears to have none of its own. Some have suggested that Toledo comes from a Hebrew root, toledoth, "geneologies," because it is known that in the sixth Century a large group of migrant Jews stopped at this place to review their family histories before going on. This would appear farfetched at best. A more likely possibility awaits investigation: there is a Celtic root, tolit-, "water, stream" which, with the appending of typical Spanish terminal vowel $-o$, would develop regularly to Toledo. The Celts are known to have lived in this region for several hundred years until the arrival of the Romans, and their toponymical traces are legion. ${ }^{26}$ The fact that Toledo is situated directly on the River Tagus would lend substance to such a supposition.

Finally among the place names are Cartagena, after Carthage; Roncesvalles, of Song of Roland fame; and Espanna, now recognized by Menéndez Pidal to be cognate with such English words as span, spanner and other concepts related to the shape of the peninsula.

21 Richardson, Vocabulary, p. 153.

22 Loss of initial $h$-is common.

23 Sebastián de Covarrubias, Tesoro de la lengua castellana o española, según la impresión de 1611 con las adiciones de Benito Remigio Noydens publicadas en 1674. Edición Martín de Ricquer. Barcelona, S.A. Horta, 1943. p. 981.

${ }^{24}$ Cejador y Frauca, in a note (II, 115-116 of the edition cited earlier) says: "En S, Vasayn; en G, Val-savin; en T, Val-sanin por Val-savin ... de vallis sapinorum, por los árboles famosos de aquel real sitio de Balsain."

${ }_{25}$ Note closing of medial /-a-/ to /-e-/ through force of preceding palatal.

${ }^{26}$ Cf. Menéndez Pidal's extensive study of the subject. (La toponimia prerrománica hispana.) 


\section{PERSONAL NAMES}

Once again, the Archpriest's knowledge of both classical history and mythology is encyclopedic. Here are direct references to Aristotle, Cato, Darius, and Helen and Paris of Troy; Ovid, whose Ars Amatoria provided the basis for a substantial portion of the Libro in which young men are instructed in the art of seduction; Plato and Hippocrates from Greek history; and, as one might anticipate, Venus from Roman mythology. Here too are Vergil, from Roman history; and Tristan, from Arthurian legend.

Other non-Spanish personal names include Acebyn, a rabbi; Alcaraz, a Moorish king; Ali, used generically to refer to the Moors; Pitas Payas, a painter of Brittany, from the ribald story of the same name that enjoyed international currency in the Middle Ages ; ${ }^{27}$ and Tholomeo, author of the Centiloquio.

The Spanish personal names involve a charming assortment of saints and rascals, both male and female: Doña Endrina, a lady who appears in that part of the Libro modelled on the Pamphilus de amore; Gadea, akin to Agatha, a mountain shepherdess; Merjelina, probably akin to modern Marjorie; Orabuena and Teresa, mistresses of the monks of Talavera; Paula, unidentified; Lloriente, unidentified; Uracca, the trotaconventos, an old woman who makes her living as a procuress; and Garoça, a nun to whom the Archpriest makes love.

Among the males are Ferrand García, a servant of the Archpriest; and Fferruzo, husband of one of the mountain girls. Don Gil, Archbishop of Toledo, appears with Gonçalo, Sancho and Múñoz, monks of Talavera, who were annoyed by don Gil's letter ordering them to get rid of their mistresses. Present also are Melón (don Melón Ortiz de la Huerta); don Polo, a lover; and, on a higher plane, Guido, author of the Rosario, a work on the decretals of Gratian. There is Rando, unidentified; and, of course, Johán Ruyz, or Juan Ruiz, the Archpriest himself.

\section{ALLEGORICAL NAMES}

Juan Ruiz, as might be expected, coined names and used them allegorically. Most noteworthy of these are don Carnal and doña

27 For a delightful and scholarly account of the transmission of this tale across Europe, see L. G. Moffatt, "Pitas Payas," in South Atlantic Studies for Sturgis E. Leavitt, Scarecrow Press, Washington, D.C., 1953. 
Cuaresma (Sir Carnival and Lady Lent). He invented the place name Valdevacas, and the personal name Santa Quiteria. He called his man-servant Hurón, "the ferret," for reasons one might without difficulty surmise. He personified the Thursday before Lent as "don Jueves Lardero." He gave the name Rama to the mother of doña Endrina, which strongly suggests the etymological relationship between rama and ramera, "prostitute." He expressed the concept John Doe, or fulano, by the popular name Pedro; the concept Jane Doe by the feminine name Menga; and in this same connection used the coined name Apodas, which Richardson believes to derive from apodo, in turn deriving from ad-putare. This was first suggested by Cejador. "If this is correct," says Richardson, "we have here almost the sole popular survival of putare - think, calculate."

Finally are the names which, for want of a better term, may be classified as "other." Names of nationalities: Arávigo, Castellano, Inglés; names of human ethnic groups: Jodio, Moro (and fem. Mora); Novela, in the legal sense of an addendum to a document; Panfilo, referring to the Pamphilus de amore; Roldán, as the title of the Maestre Rolando, written in the previous century by order of Alfonso the Wise; Reportorio, a legal treatise by Guillermo Durante; Espéculo, meaning the Speculum Iuris by the same author; and Ysopete, referring to the French collection of Aesopic fables.

Any one of these names raises questions - literary, philological, social, historical, ecclesiastical or motivational - that can be answered only with years of patient study. A single example: the place name Talavera.

Although it is possible to derive the word talavera from a combination of Arabic and Latin, there is nevertheless a possibility of a preRomance origin.

Los más eruditos concuerdan todos en el nombre Ebura como originario de Talavera, y sólo discrepan en la radical que pretenden ser necesaria, además, para la explicación completa de la formación de este nombre. Mariana, que trató detenidamente de Talavera de la Reina, conjectura así sobre su nombre: "Sospecho que Tala, en la lengua antigua de España, es lo mismo que pueblo ... y que Tala y Ebura, primero se llamó Talebura o Talabura, y de aquí, con pequeña mudanza, se forjó el nombre de Talavera." 28

While at first the above idea may appear quite far-fetched, there is at least some supporting historical evidence. In A.D. 182, one

${ }^{28}$ Enciclopedia universal ilustrada, XLIX, 15. 
Q. Fulvius Flaccus, praetor in the Tarracona province against whom the Celtiberians were taking up arms, wrote that he was uniting his troops on the banks of the Tagus nor far from Toledo and very near Ebura (ad oppidum Eburam), the present site of Talavera. ${ }^{29}$

On the other hand, there is an Arabic word Tala or Talat, meaning a path up a mountainside or ravine. ${ }^{30}$ This noun, taken together with Spanish vera, meaning "orilla," akin to ribera from Latin riparium, could be aptly applied to present Talavera since it is located near the Tagus, whose escarped contours are well known.

Arabic? Latin? Latin and Arabic? Indigenous? Indigenous and Arabic? This name, Talavera, is representative of the enigmas implicit in scores of names in the Libro.

The Archpriest has, by this onomastic tour de force, thrown down a very considerable challenge - not to the philologist alone, but to historians in half a dozen disciplines.

\section{APPENDIX OF PROPER NAMES IN THE LIBRO DE BUEN AMOR*}

Name
Abel
Abrahan (Abraham)
Açebyn
Açipreste
Adán (Adam)
Agostyn (Augustine)
Ala (Allah)
Alarcos
Alberche
Alcalá
Alcántara
Alcaraz
Alcudia
Alexandría
Algueva

$\begin{array}{ll}\text { Type of Concept } & \text { Line }(s) \text { No. } \\ \text { person } & 281 \mathrm{~A} \\ \text { person } & 1561 \mathrm{C} \\ \text { person } & 1184 \mathrm{~A} \\ \text { title (eccl.) } & 19 \mathrm{C}, 575 \mathrm{~A} \\ \text { person } & 294 \mathrm{~A}, 1561 \mathrm{~A} \\ \text { person } & 1238 \mathrm{C} \\ \text { divinity } & 1510 \mathrm{D} \\ \text { place (Spanish) } & 1110 \mathrm{D} \\ \text { stream (Spanish) } & 1105 \mathrm{D} \\ \text { place (Spanish) } & 1312 \mathrm{~B}, 1510 \mathrm{~A} \\ \text { place (Spanish) } & 1114 \mathrm{~B}, 1237 \mathrm{~B} \\ \text { place (Spanish) } & 129 \mathrm{~A} \\ \text { place (Spanish) } & 1187 \mathrm{~A} \\ \text { place } & 1335 \mathrm{~A}, 1338 \mathrm{~A} \\ \text { place (Spanish) } & 983 \mathrm{C}\end{array}$

29 Ibid.

30 Alexander Knox, Glossary of Geographical and Topographical Terms, London, E. Stanford. Longacre, 1904, p. 370.

* Based on the edition cited in footnote No. 2, first page of this article. This (Cejador's) is in turn based principally on Ms. G (Gayoso). 


\begin{tabular}{|c|c|c|}
\hline Name & Type of Concept & Line $(s)$ No. \\
\hline Almuerço (don) & person, allegorical & $1191 \mathrm{~B}, 1196 \mathrm{~A}, 1197 \mathrm{~B}$ \\
\hline Aly $(A l i)$ & person, allegorical & $1088 \mathrm{C}$ \\
\hline Amor (don) & person, allegorical & $\begin{array}{l}1211 \mathrm{~A}, 1211 \mathrm{D}, 1225 \mathrm{D}, \\
1299 \mathrm{~A}, 1313 \mathrm{~B}\end{array}$ \\
\hline Andalusía & place (Spanish) & $1304 \mathrm{~B}$ \\
\hline Antón (Antonio) (Sant) & person & $1240 \mathrm{~A}$ \\
\hline Apocalisi (Apocalypse) & abstraction, biblical & $1011 \mathrm{~A}$ \\
\hline Apodas & person, allegorical & $1329 \mathrm{D}$ \\
\hline Arávigo (Arabic) & language & $1516 \mathrm{~A}, 1517 \mathrm{~B}$ \\
\hline Aristótiles (Aristotle) & person & $71 \mathrm{~A}$ \\
\hline Asuero (Ahasuerus) & person & $2 \mathrm{~B}$ \\
\hline \multicolumn{3}{|l|}{ Atora (see Tora) } \\
\hline Ayuno (don) & person, allegorical & $1181 \mathrm{~A}$ \\
\hline Babilón (Babylon) & place & $1 \mathrm{C}$ \\
\hline Bablyonia & place & $305 \mathrm{~B}$ \\
\hline Baltasar & person & $27 \mathrm{C}$ \\
\hline Barçilona & place (Spanish) & $1243 \mathrm{D}$ \\
\hline Bayona (Bayonne) & place & $1107 \mathrm{~A}$ \\
\hline Belén (Bethlehem) & place & $25 \mathrm{~A}$ \\
\hline Benito (Sant) & person & $1236 \mathrm{~A}$ \\
\hline Berdones & place & $1235 \mathrm{D}$ \\
\hline Bermeo & place (Spanish) & $1112 \mathrm{D}$ \\
\hline Berssabe (Bathsheba) & person & $259 \mathrm{~A}$ \\
\hline Boloña (Bologne) & place & $1517 \mathrm{~B}$ \\
\hline Bretaña (Brittany) & place & $474 \mathrm{C}$ \\
\hline Buenaval & place (Spanish) & $1237 \mathrm{~B}$ \\
\hline \multirow[t]{2}{*}{ Bugía (Bougie) } & place & 323C (Buxía) \\
\hline & & $325 \mathrm{~B}, 348 \mathrm{~B}$ \\
\hline Burgos & place (Spanish) & $1073 \mathrm{D}$ \\
\hline Caçres* & place (Spanish) & $1186 \mathrm{~A}$ \\
\hline Calataút (Calatayud) & place (Spanish) & $582 \mathrm{C}$ \\
\hline \multirow[t]{2}{*}{ Calatrava } & (1) place (Spanish) & $1187 \mathrm{~A}, 1237 \mathrm{~B}$ \\
\hline & (2) military order & \\
\hline Carmen & religious order & $1239 \mathrm{~A}$ \\
\hline Carnal & person, allegorical & $1070 \mathrm{~B}, 1074 \mathrm{D}, 1075 \mathrm{C}$ \\
\hline & & $1079 \mathrm{C}, 1080 \mathrm{~A}, 1081 \mathrm{~B}$ \\
\hline & & $1103 \mathrm{D}, 1114 \mathrm{C}, 1118 \mathrm{C}$, \\
\hline & & $1120 \mathrm{~B}, 1127 \mathrm{~A}, 1128 \mathrm{C}$, \\
\hline & & $1161 \mathrm{C}, 1162 \mathrm{~A}, 1180 \mathrm{~B}$, \\
\hline & & $1182 \mathrm{~B}, 1185 \mathrm{C}, 1190 \mathrm{~B}$, \\
\hline
\end{tabular}

* The edition of Cejador shows the form cánçeres, which demonstrates clearly the confusion that still existed as late as the 14th Century regarding the dropping of /-n-/ before a sibilant. We must bear in mind that the grapheme -ç- represented the phonemes /-ts-/ at this time. 
Name

Cartajena

Castro (de Ordiales)

Cayn (Cain)

Casimodo (Quasimodo)

Castellano

Castiella

Catón (Cato)

Çeçina

Çistel (the Cistercians)

Cornejo

Crementinas (the Clementines)

Cruzniego (Cluny)

Cuarsema (Quaresma)

Dalyla (Delilah)
Dan
Daniel
Dário (Darius)
David
Dios

Duero

Egipto (Egypt)

Elena (Helen of Troy)

Endryna

Esaú

Espanna (España)

Espéculo
Ester (Esther)
Eulalya (Eulalia)
$\quad \quad$ (Santolalla)
Eua, Eva (Eve)
Ezechías (Ezekiah)
Faraón (Pharoah)
Fazaluaro (Hazalvaro)
Ferrand
Ferreros
Fferruzo (Herroso)

Type of Concept

place (Spanish)
place (Spanish)
person
abstraction
language
place (Spanish)
person
person, allegorical
religious order
nickname (Spanish)
religious order
religious order
abstraction, religious

person

person

person

person

person

divinity

river (Spanish)

place

person

person

person

place

literary title

person

person

person

person

person (also title)

place

person

place (Spanish)

person
Line (s) No.

$1193 \mathrm{~B}, 1209 \mathrm{~B}, 1212 \mathrm{~A}$, $1216 \mathrm{~A}, 1302 \mathrm{D}, 1311 \mathrm{D}$

$1146 \mathrm{~A}$

$1073 \mathrm{D}, 1119 \mathrm{C}, 1311 \mathrm{~B}$

$281 \mathrm{~A}, 1561 \mathrm{~B}$ (Can)

$1315 \mathrm{~A}$

$1224 \mathrm{~B}$

1222 A, 1696D (Castilla)

$44 \mathrm{~A}, 568 \mathrm{C}$

$1106 \mathrm{C}, 1125 \mathrm{D}$

$1236 \mathrm{~A}$

$980 \mathrm{C}$

(intro.)

$1236 \mathrm{~B}$

$1067 \mathrm{C}, 1069 \mathrm{~A}, 1075 \mathrm{~A}$,

$1099 \mathrm{~B}, 1102 \mathrm{D}, 1125 \mathrm{C}$,

$1189 \mathrm{C}, 1190 \mathrm{C}, 1194 \mathrm{C}$,

$1198 \mathrm{C}, 1202 \mathrm{~A}$

308B

$1561 \mathrm{D}$

1C, $1061 \mathrm{E}$

$1215 \mathrm{D}$

$258 \mathrm{~A}$

1A, 3D, 4C, 8B, 105D, $107 \mathrm{~A}, 834 \mathrm{~B}$, etc.

(Par Dios)

$246 \mathrm{C}$

$224 \mathrm{~A}$

$223 \mathrm{D}$

$596 \mathrm{~A}, 653 \mathrm{~A}, 665 \mathrm{~A}$,

$669 \mathrm{~A}, 679 \mathrm{~A}, 685 \mathrm{~A}$,

$281 \mathrm{C}$

$122 \mathrm{C}, 304 \mathrm{~B}, 621 \mathrm{C}$,

$1244 \mathrm{D}$

$1152 \mathrm{~A}$

$2 \mathrm{~A}$

$1239 \mathrm{~B}$

(1) $378 \mathrm{D}, 1561 \mathrm{~B}$

$1143 \mathrm{~A}$

$1 \mathrm{~B}$

$1187 \mathrm{~B}$

$117 \mathrm{~B}, 913 \mathrm{~A}$

$985 \mathrm{D}, 1028 \mathrm{C}$

$980 \mathrm{~A}$ 
Name

Françia

Françisco (Sant)

Frandes (Flanders)

Fita

Gadea

Galilea (Galilee)

Garçia

Garoça

Gaspar

Gaula

Gentiles

Gil (don Gil de Albornoz)

Gonçalo

Grabiel (Gabriel)

Granada

Greçia (Greece)

Gregorio

Guadalajara

Guadalquivir

Guido

Henares

Hemanuel (Emmanuel)

Hurón

Inglés

Inocençio (Innocent IV)

Jaab (Joab)

Jacob

Jafet (Japhet)

Jeremías (Jeremiah)

Jerusalén (Jerusalem)

Jhesu, Jhesuxristo

(Jesus)
Type of Concept

place

person

place

place (Spanish)

person

place

person

person

person

place

collective of persons

person

person

person

place

place

person

place (Spanish)

river (Spanish)

person

place (Spanish)

person

nickname (Spanish)

language

person

person

person

person

person

place

person and divinity

person

collective of Jews

person

person

person
Line (s) No.

$1244 \mathrm{C}$

$1238 \mathrm{~B}$

$475 \mathrm{~B}, 481 \mathrm{~A}$

$19 \mathrm{C}, 575 \mathrm{~A}, 845 \mathrm{~A}$

$987 \mathrm{C}, 988 \mathrm{C}$

$22 \mathrm{~B}$

$117 \mathrm{~B}, 913 \mathrm{~A}$

$1346 \mathrm{~A}, 1392 \mathrm{~A}, 1395 \mathrm{~A}$, 1484A, 1492A

$27 \mathrm{~A}$

$1278 \mathrm{C}$

$3 \mathrm{~B}$

$1690 \mathrm{~B}$

$1708 \mathrm{~A}$

$8 \mathrm{C}, 23 \mathrm{~B}, 38 \mathrm{C}$

$1215 \mathrm{~B}$

$46 \mathrm{~B}, 46 \mathrm{D}, 58 \mathrm{~A}$

(intro.)

1370 A, 1371D, 1377 A

$1107 \mathrm{D}$

$1152 \mathrm{D}$

$170 \mathrm{~B}, 1107 \mathrm{C}$

8A, 9B

$1619 \mathrm{C}$

$1224 \mathrm{~B}$

$1152 \mathrm{C}$

$258 \mathrm{D}$

$281 \mathrm{C}$

$1561 \mathrm{C}$

$1060 \mathrm{C}$

$1202 \mathrm{C}$

$21 \mathrm{~B}, 32 \mathrm{~B}, 38 \mathrm{D}, 89 \mathrm{D}$, $282 \mathrm{~A}, 1048 \mathrm{~F}, 1049 \mathrm{~B}$, $1053 \mathrm{~B}, 1059 \mathrm{~B}, 1061 \mathrm{~F}$, $1069 \mathrm{D}, 1142 \mathrm{~B}, 1556 \mathrm{~B}$, $1560 \mathrm{~B}, 1568 \mathrm{C}, 1605 \mathrm{D}$, $1641 \mathrm{G}, 1645 \mathrm{~B}, 1657 \mathrm{~B}$, $1670 \mathrm{~F}$

(intro.)

$1 \mathrm{~A}, 78 \mathrm{D}, 309 \mathrm{~B}, 554 \mathrm{C}$, $1063 \mathrm{~F}, 1193 \mathrm{C}$

$19 \mathrm{~B}, 575 \mathrm{~A}$

$5 \mathrm{~A}$

$1049 \mathrm{G}, 1051 \mathrm{~B}, 1063 \mathrm{C}$ 


\begin{tabular}{|c|c|c|}
\hline Name & Type of Concept & Line(s) No. \\
\hline Judea & place & $1049 \mathrm{C}$ \\
\hline Judería & place (ghetto) (Spanish) & $1183 \mathrm{~A}$ \\
\hline Julián & person & $963 \mathrm{~B}$ \\
\hline Jupiter & divinity & $\begin{array}{l}199 \mathrm{D}, 200 \mathrm{~A}, 201 \mathrm{C} \\
203 \mathrm{~A}, 205 \mathrm{~A}\end{array}$ \\
\hline Laredo & place (Spanish) & $1118 \mathrm{~A}$ \\
\hline Lasaro (Lazarus) & person & $247 \mathrm{~B}$ \\
\hline \multicolumn{3}{|l|}{ Loc $(\operatorname{See} L o t)$} \\
\hline Loçoya & place (Spanish) & $951 \mathrm{~B}, 974 \mathrm{~B}$ \\
\hline Lot & person & $296 \mathrm{~A}, 528 \mathrm{C}$ \\
\hline Lucifer & person, allegorical (devil) & $233 \mathrm{~B}$ \\
\hline Llorente & person & $1004 \mathrm{G}$ \\
\hline Madalena (Magdalena) & person & $28 \mathrm{~B}, 1141 \mathrm{C}, 1713 \mathrm{~A}$ \\
\hline Malangosto & place (Spanish) & $959 \mathrm{~B}$ \\
\hline Manual & $\begin{array}{l}\text { title (confessor's } \\
\text { handbook) }\end{array}$ & $1148 \mathrm{C}$ \\
\hline Marcos (Sant) & person & $1321 \mathrm{~A}$ \\
\hline María & person & $\begin{array}{l}19 \mathrm{~B}, 20 \mathrm{~A}, 34 \mathrm{E}, 913 \mathrm{D}, \\
1044 \mathrm{~B} \text { (Santa María del } \\
\text { Vado) } 1060 \mathrm{H}, 1310 \mathrm{C} \text {, } \\
1633 \mathrm{D} \text { (Avé María) }\end{array}$ \\
\hline Marina (Santa) & person & $3 \mathrm{C}$ \\
\hline Marta & person & $1639 \mathrm{C}$ \\
\hline Medelín & place (Spanish) & $1184 \mathrm{C}, 1186 \mathrm{~A}$ \\
\hline Meder (Sant) (Emeterius) & person & $951 \mathrm{~A}$ \\
\hline Melchior & person & $27 \mathrm{~B}$ \\
\hline Melón & person & $873 \mathrm{D}, 891 \mathrm{~A}$ \\
\hline de la Huerta & & $727 \mathrm{C}, 738 \mathrm{D}$ \\
\hline Ortiz & & $881 \mathrm{D}$ \\
\hline Melinas (Malines) & place & $1394 \mathrm{D}$ \\
\hline Menga (Mengua) & collective of women & $939 \mathrm{~B}, 1004 \mathrm{D}$ \\
\hline Merienda (doña) & person, allegorical & $1195 \mathrm{D}$ \\
\hline Merjelina & person & $211 \mathrm{C}$ \\
\hline Mexía (Mexías) (Messiah) & divinity & $5 \mathrm{D}, 25 \mathrm{D}, 1635 \mathrm{D}, 1647 \mathrm{~B}$ \\
\hline Migel (Miguel) (Sant) & person & $829 \mathrm{D}, 1717 \mathrm{~B}$ \\
\hline Monferrado & place (Spanish) & $1370 \mathrm{~B}, 1372 \mathrm{~B}$ \\
\hline Mongibel & place (Spanish) used & $281 \mathrm{~B}$ \\
\hline \multicolumn{3}{|c|}{ allegorically to mean hell } \\
\hline Monpeller & place & $1338 \mathrm{~A}$ \\
\hline Mora & $\begin{array}{l}\text { collective of } \\
\text { Moorish women }\end{array}$ & $\begin{array}{l}1508 \mathrm{C}, 1509 \mathrm{~A}, 1509 \mathrm{D}, \\
1510 \mathrm{D}, 1511 \mathrm{D}, 1512 \mathrm{D}\end{array}$ \\
\hline Moro & $\begin{array}{l}\text { collective of } \\
\text { Moorish men }\end{array}$ & $129 \mathrm{~A}, 1193 \mathrm{C}, 1215 \mathrm{~B}$ \\
\hline Moya & place (Spanish) & $972 \mathrm{D}$ \\
\hline
\end{tabular}




\begin{tabular}{|c|c|c|}
\hline Name & Type of Concept & Line $(s)$ No. \\
\hline Muñós & person & $1705 \mathrm{~A}$ \\
\hline $\begin{array}{l}\text { Nabucodonossor } \\
\quad \text { (Nebuchadnezzar) }\end{array}$ & person & $305 \mathrm{~A}$ \\
\hline Nasón & person & $429 \mathrm{D}, 891 \mathrm{D}$ \\
\hline Nazaret (Nazareth) & place & $22 \mathrm{C}$ \\
\hline Novela & legal term & $1152 \mathrm{D}$ \\
\hline Orabuena & person & $1698 \mathrm{~A}, 1699 \mathrm{C}$ \\
\hline Ordeales (Urdiales) & place (Spanish) & $1073 \mathrm{D}, 1119 \mathrm{C}$ \\
\hline Oropesa & place (Spanish) & $1702 \mathrm{C}$ \\
\hline Ortiz & person & $881 \mathrm{D}$ \\
\hline Ospital (Hospitalers) & religious order & $1237 \mathrm{~A}$ \\
\hline Ostiense & place (Spanish) & $1152 \mathrm{~B}$ \\
\hline Ovydio (Ovidio, Ovydyo) & person & $429 \mathrm{~A}, 446 \mathrm{C}, 612 \mathrm{~A}$ \\
\hline Panfilo & $\begin{array}{l}\text { title (Pamphilus } \\
\text { de amore) }\end{array}$ & $429 \mathrm{D}, 698 \mathrm{C}, 891 \mathrm{D}$ \\
\hline Paris & person, place & $\begin{array}{l}\text { 223C (Paris of Troy) } \\
1243 \mathrm{D} \text { (city of Paris) }\end{array}$ \\
\hline Paula & person & $1278 \mathrm{D}$ \\
\hline Pablo & person & $875 \mathrm{C}, 1238 \mathrm{~A}$ \\
\hline \multirow[t]{2}{*}{ Pedro } & (1) collective of men & $\begin{array}{l}486 \mathrm{~A}, 486 \mathrm{C}, 487 \mathrm{~A} \\
\text { (Fulano) }\end{array}$ \\
\hline & (2) saint & 6C, 1142 A (Sant) \\
\hline Pilatos (Pilate) & person & $1052 \mathrm{E}$ \\
\hline $\begin{array}{l}\text { Pitas Payas (Pytas Pajas, } \\
\text { Pitas Pajas) }\end{array}$ & person & $\begin{array}{l}474 \mathrm{C}, 476 \mathrm{~A}, 477 \mathrm{~B} \\
480 \mathrm{D}, 482 \mathrm{~A}, 483 \mathrm{~A}\end{array}$ \\
\hline Plasençia & place (Spanish) & $1186 \mathrm{~B}$ \\
\hline Platón (Plato) & person & $124 \mathrm{~A}$ \\
\hline Polo & person & $1331 \mathrm{C}$ \\
\hline Purgatorio & abstraction & $1140 \mathrm{~B}$ \\
\hline \multicolumn{3}{|l|}{ Quaresma (see Cuaresma) } \\
\hline Quiteria & person, fictitious & $1312 \mathrm{~B}$ \\
\hline Rama & person & $812 \mathrm{C}, 824 \mathrm{C}, 825 \mathrm{~A}$ \\
\hline Ramos (domingo de) & religious feast day & $1181 \mathrm{C}$ \\
\hline Rando & person & $972 \mathrm{D}$ \\
\hline Requena & place (Spanish) & $1146 \mathrm{~B}$ \\
\hline Río Frío & stream (Spanish) & $987 \mathrm{C}$ \\
\hline Rodas & place, allegorical & $1329 \mathrm{~A}$ \\
\hline Ruyz (Rruyz) (Ruiz) & person & $19 \mathrm{~B}, 575 \mathrm{~A}$ \\
\hline Roldán (Roland) & person & $556 \mathrm{~A}$ \\
\hline Roma & place & $\begin{array}{l}46 \mathrm{D}, 58 \mathrm{D}, 262 \mathrm{D}, 266 \mathrm{~A}, \\
493 \mathrm{~A}, 1146 \mathrm{~A}\end{array}$ \\
\hline Ronçesvalles & place & $1209 \mathrm{C}$ \\
\hline Rosario & literary title & $1152 \mathrm{D}$ \\
\hline Salamo (Solomon) & person & $105 \mathrm{~A}$ \\
\hline Sancho & person & $1705 \mathrm{~A}$ \\
\hline
\end{tabular}


Name

Sanssón (Samson)

Sant Ander

Santiago

Santillán (St. Julian)

Sapiençia

Satán

Saúl

Sed (Seth)

Ssegovia

Sevilla

Sierra Nevada

Sotos Alvos

Soria

Susaña (Susanna)

Tablada

Talavera

Teresa

Tholomeo

Tiberio

Toçino (don)

Toledo

Tora (Atora) (Torah)

Toro

Trenidat (Trinity)

Tristán

Troxiello

Troya

Urías (Uriah)

Urraca

Vado

Valdemoriello

Valdevacas

Valençia

Valsavin

Venus

Vera

Virgillio (Vergilio)

Visagra

Vyllenchón

Xristiano
Type of Concept

person

place (Spanish)

(1) person

(2) place

person

literary title

abstraction, religious

person

person

place (Spanish)

place (Spanish)

place (Spanish)

place (Spanish)

place (Spanish)

person

place (Spanish)

place (Spanish)

person

person

river

person, allegorical

place (Spanish)

literary title

place (Spanish)

abstraction, religious

person, legendary

place (Spanish)

place

person

person

place (Spanish)

place (Spanish)

place, fictitious

place (Spanish)

place (Spanish)

divinity

place (Spanish)

person

place (Spanish)

place (Spanish)

collective of Christians
Line(s) No.

$308 \mathrm{~A}$

$1111 \mathrm{~A}$

3B, 1043 A, $1237 \mathrm{~A}$

871 A (city)

$963 \mathrm{~B}$

(intro.)

$1541 \mathrm{D}$

$309 \mathrm{~A}$

$1561 \mathrm{~B}$

$972 \mathrm{~A}$

$1114 \mathrm{~B}, 1304 \mathrm{~A}$

$1029 \mathrm{E}$

$960 \mathrm{~B}$

$1222 \mathrm{~A}$

$4 \mathrm{~A}$

1009D, 1022 A

$1690 \mathrm{~A}, 1694 \mathrm{~B}, 1702 \mathrm{C}$

$1702 \mathrm{~B}$

$124 \mathrm{~A}$

$266 \mathrm{~B}$

$1106 \mathrm{~B}$

$471 \mathrm{C}, 657 \mathrm{~A}, 1269 \mathrm{~B}$,

$1305 \mathrm{~A}$

$78 \mathrm{D}, 1053 \mathrm{C}$

$1339 \mathrm{~B}$

$1239 \mathrm{~A}$

$1703 \mathrm{~B}$

$1186 \mathrm{~A}$

$223 \mathrm{~A}$

$258 \mathrm{~B}, 259 \mathrm{~A}$

919C, 923 A, 939A,

$942 \mathrm{~B}, 1325 \mathrm{D}, 1326 \mathrm{~B}$

$1044 \mathrm{~B}$

$1186 \mathrm{~B}$

$1197 \mathrm{D}$

$1105 \mathrm{~A}, 1338 \mathrm{~A}$

$1187 \mathrm{~B}$

$152 \mathrm{~A}, 223 \mathrm{C}, 525 \mathrm{C}$,

$583 \mathrm{C}, 585 \mathrm{~A}, 601 \mathrm{D}$

$1186 \mathrm{~B}$

$261 \mathrm{~B}, 264 \mathrm{D}$

265 B, 267 D

$1306 \mathrm{D}$

$1115 \mathrm{D}$

776 D, 1172D, 1177C, 
Name

Ypocras (Hippocrates)

Ysac (Isaac)

Ysayas (Isaiah)

Ysopete

Ysrael
Type of Concept

person

person

person

abstraction from Aesop

place
Line $(s)$ No.

$1179 \mathrm{~A}, 1193 \mathrm{C}, 1321 \mathrm{C}$, $1649 \mathrm{~A}$

$303 \mathrm{C}$

$1561 \mathrm{D}$

$1060 \mathrm{E}$

$96 \mathrm{D}$

$8 \mathrm{~B}$

Ohio University

NAMES IN BRIEF : PHOEBE SNOW (I: 131)

A newsstory of the Associated Press datelined Hoboken, New Jersey, notes the passing of the famed passenger train, the Phoebe Snow. The San Francisco Examiner headlines, "She's Headin' for Last Roundhouse" (November 20, 1966, p. 15/1-2).

Mark Sullivan, Our Times, The United States, 1900-1925, dates a famed "Miss Phoebe Snow" advertisement of the Lackawanna Railroad May 15, 1904, printing the accompanying verse (II, p. 619). Some writers age Phoebe in the 1890's, while Freeman H. Hubbard, Railroad Avenue, writes "the dainty young lady ... made her debut in newspaper, magazine and car-card advertisement of July, 1904 (1945: New York, McGraw-Hill, pp. 39-41). The Lackawanna Story, Robert J. Casey and W. A. S. Douglas (1951: New York, McGraw-Hill), reprints drawings and verse of this figure of American folklore. B. A. Botkin and Alvin F. Harlow, A Treasury of Railroad Folklore (1953: Crown, pp. 390-392), adequately sk et ch the career of this personification, long in advertising's hall of fame, printing a good selection of the jingles associated with her.

Appropriate to our transsexual time, the AP reports that on the final trip of the Phoebe Snow a male cashier of Bound Brook, N.J., dressed in white to symbolize this famed female. 